\title{
Primary diffuse large B-cell lymphoma of the oral cavity
}

\author{
Linfoma difuso de grandes células B primário de boca
}

Bruno Correia Jham, 2; Eliza Carla Barroso Duarte'; Anacélia Mendes Fernandes; Aline Cristina Batista Rodrigues Johann'; Maria Cássia Ferreira Aguiar3; Ricardo Santiago Gomez ${ }^{3}$; Ricardo Alves Mesquita ${ }^{3}$

\section{abstract}

Lymphomas arising within the oral cavity account for only $3.5 \%$ of all oral malignancies. Diffuse large B-cell lymphoma is a non-Hodgkin lymphoma subtype characterized by diffuse proliferation of large neoplastic B lymphoid cells. This paper reports a case of diffuse large B-cell lymphoma affecting the oral cavity of a Brazilian woman, along with its clinical, microscopical, immunohistochemical, and

\section{Background}

Diffuse large B-cell lymphoma (DLBCL) is a nonHodgkin lymphoma (NHL) subtype characterized by diffuse proliferation of large neoplastic B lymphoid cells with nuclear size equal to or exceeding normal macrophage nuclei, or more than twice the size of a normal lymphocyte ${ }^{(7)}$.

Affected patients are usually in their seventh decade of life, and the clinical aspect is typically a rapidly enlarging, often symptomatic mass ${ }^{(7)}$. The most commonly affected site of NHL of the oral cavity and maxillofacial region is the Waldeyer's ring: tonsils, nasopharynx, base of the tongue, and palatine tonsil ${ }^{(8)}$. Currently, the treatment

\begin{abstract}
key words
Diffuse large B-cell
lymphoma
Non-Hodgkin lymphoma
Oral cancer
molecular features.

\section{resumo}

Linfomas correspondem a 3,5\% de todos os casos de lesões malignas de boca. O linfoma difuso de grandes células B é um subtipo de linfoma não-Hodgkin caracterizado pela proliferação difusa de células linfóides $B$. Este artigo relata um caso de linfoma difuso de grandes células $B$ localizado na cavidade bucal de uma mulher brasileira, incluindo os achados clínicos, microscópicos, imuno-histoquímicos e moleculares.
\end{abstract}


that had been increasing in size for the past six months. Extraoral examination revealed asymmetry and swelling of the right side of the face (Figure 1A). Intra-oral exam showed a soft mass on the right side of the palate, containing two $3-\mathrm{cm}$ eroded areas (Figure 1B). Computed tomography revealed destruction of the maxilla and zygomatic bone and invasion of soft tissue on the right side (Figure 1C), as well as invasion of the nasal cavity and maxillary sinus of the opposite side. There were no signs of the disease elsewhere in the body. Clinical diagnoses were mucoepidermoid carcinoma or maxillary sinus carcinoma. An incisional biopsy was performed, with histology showing neoplastic sheets of lymphoid cells with a solid growth pattern. Individually, cells showed scarce cytoplasm and large nucleus (Figure 1D). Sections were submitted to immunohistochemical evaluation, and the malignant cells were immunopositive for LCA and CD20 (Figure 1E). AE1/AE3, CD3, CD10, CD45RO, and S-100 were immunonegative. Following extraction of the genomic DNA, heavy immunoglobulin gene rearrangement $(\mathrm{lgH})$ analysis was performed ${ }^{(3,6,10)}$. The obtained DNA showed a discrete and homogeneous band on electrophoresis (Figure 1F, line 3). Final diagnosis was diffuse large B-cell lymphoma. The treatment consisted of dexamethasone, cyclophosphamide, vincristine, etoposide, carboplatin, adriamycin, and iphosphamide. Initially, the patient showed significant clinical improvement (Figures 1G and 1H). However, after being submitted to five cycles of chemotherapy, she unfortunately passed away.

\section{Discussion}

Clinical, microscopic, immunohistochemical and molecular features of the reported case confirm the diagnosis of primary DLBCL of the oral cavity. Following squamous cell carcinoma, lymphomas are the second most common neoplasm of the head and neck ${ }^{(8)}$. Nevertheless, the etiology of DLBCL remains unknown. They may originate de novo or represent progression from a less aggressive lymphoma, such as follicular lymphoma or small lymphocytic lymphoma. Underlying immunodeficiency is a significant risk factor, and DLBCL in the setting of immunodeficiency is more often Epstein-Barr virus-positive than sporadic $\operatorname{DLBCL}^{(3,7)}$. In accordance to the analysis of global gene expression employing DNA microarrays, DLBCL was broadly divided into normal germinal center B-cells (GC-like DLBCL) or activated peripheral blood B-cells (ABC-like DLBCL). Cytogenetically, GC-like lymphomas present $\mathrm{t}(14 ; 18)(q 32 ; q 21)$ translocations involving the
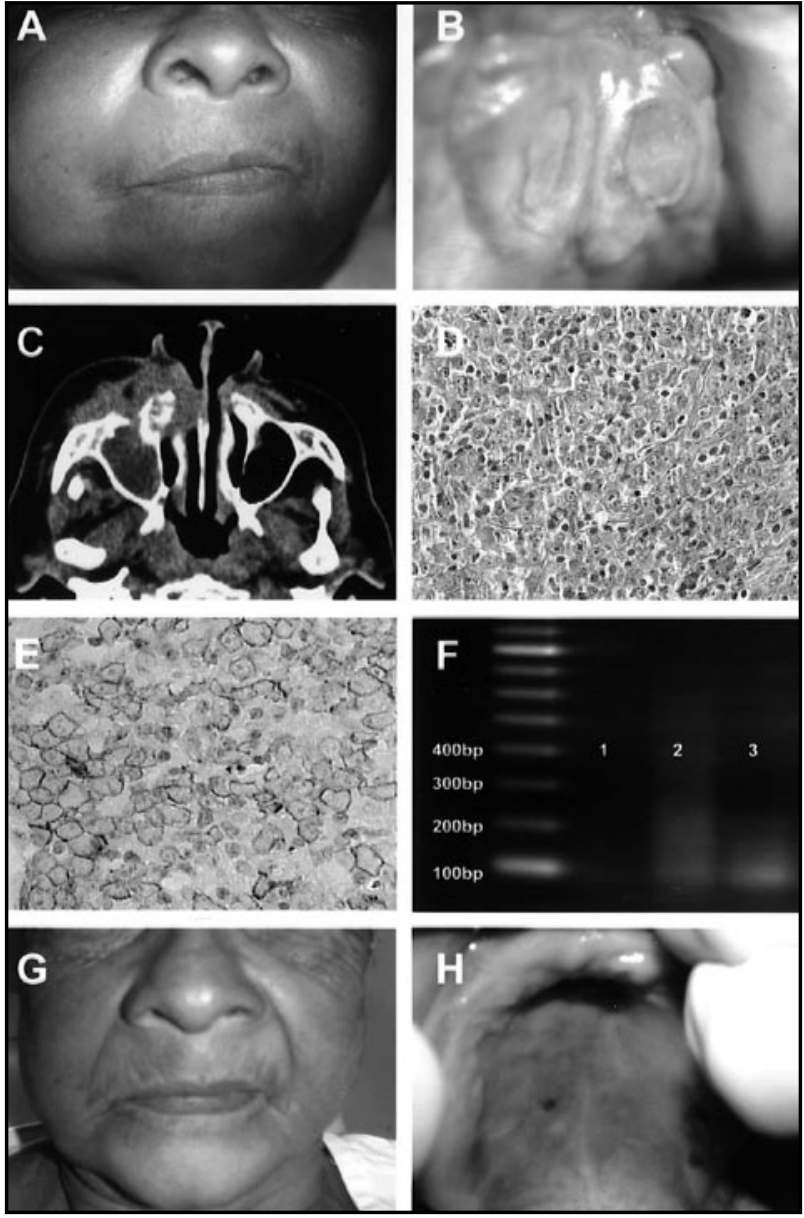

Figure 1 - A: Asymmetry and swelling of the right side of the face; $B$ : tumoral swelling in the palate with two 3-cm eroded areas; $C$ : computed tomography demonstrated invasion of maxillary sinus, nasal cavity and soft tissue of the right side; D: neoplastic cells are represented by centroblasts (large cell with two or more nucleolus) and immunoblasts (large with one nucleolus) (haematoxilin and eosin, original magnification 400x); $E$ : immunoblasts and centroblasts are CD20-positive (streptoavidin-biotin technique; Dako Corporation, Carpinteria, CA, USA; clone L26; dilution 1:50, antigen retrieval with 0.01 $\mathrm{M}$ citric acid, $\left.95^{\circ} \mathrm{C}, 30 \mathrm{~min}\right) ; \mathrm{F}: \mathrm{lgH}$ analysis demonstrated a discrete and homogenous band of approximately 80 bp on electrophoresis (line 3) (polymerase chain reaction technique, bp: base pairs; line 1: negative control, line 2: polyclonal pattern-tonsil; line 3: current case-monoclonal pattern); $\mathrm{G}$ and $\mathrm{H}$ : patients following three cycles of chemotherapy. Clinical improvement was observed

BCL-2 gene and the amplification of the c-rel locus on chromosome $2 \mathrm{p}$. In this tumor subtype, oncogenesis is related to $B C L-6$ expression. In contrast, $A B C$-like tumors demonstrate trisomy 3 , gains of $3 q$ and 18q21-q22, and losses of 6 q21-22; in this case, oncogenesis is associated with expression of NF- $\mathrm{KB}$ target genes resulting from a constitutive activity of inhibitor kappa B ( $\mid \kappa B)$ kinase ${ }^{(11)}$.

Lymphomas arising within the oral cavity, such as in our case, account for only $3.5 \%$ of all oral malignancies. In the oral cavity, lymphomas usually present as an extranodal, soft-elastic, asymptomatic lesion ${ }^{(4)}$. One study reviewed forty cases of oral lymphomas and verified that in $66 \%$ of the cases, the lesion arose from soft tissues, and $77 \%$ of 
these were seen in the upper jaw ${ }^{(14)}$. Likewise, our patient showed a soft, asymptomatic lesion on the upper jaw. The lesion was mainly located in the palate; however, it was clinically difficult to precisely determine its limits and to define whether or not it extended into maxillary alveolar ridge.

The diagnosis of oral lymphomas may be challenging because frequently there is a low index of clinical suspicion, leading to misdiagnosis and/or delayed treatment. For instance, in a superficial biopsy specimen, superimposed inflammatory changes can result in a lymphoma being mistaken for a reactive or infectious process ${ }^{(12)}$. Thus, biopsies should be carefully performed to obtain adequate specimens. On the other hand, recent advances have made it possible to investigate lymphomas for the expression of a wide range of antigens in fixed tissues. Although standard hematoxylin- and eosin-stained sections still provide the basis for all lymphoma diagnosis, immunophenotyping (IP) is by far the most common ancillary technique used today. IP is useful both for distinguishing benign from malignant processes as well as for accurate subclassification with high sensibility and specificity. In addition, IP allows diagnosis on small biopsies that would have previously been deemed inadequate for diagnosis ${ }^{(5)}$. Furthermore, detection of $\operatorname{lgH}$ at the DNA level by use of polymerase chain reaction (PCR) to assess monoclonality has become a routine technique in the initial diagnosis of lymphoproliferative disorders. Clonality assays are useful for distinguishing reactive or benign lymph nodes from neoplastic lymphoid infiltrates in most cases. In addition, the inclusion of T-cell antigen receptors in the assessment of lymphomas results in a significant increase in the sensitivity of clonality detection ${ }^{(9)}$. Furthermore, microarrays are powerful tools for discovery and hypothesis generation, allowing researchers to obtain an unbiased survey of gene expression in lymphoma samples. However, their direct clinical application for individualized diagnosis has been questioned ${ }^{(11)}$. In the reported case, immunohistochemistry and IgH analysis were essential for diagnosis and classification.

NHLs are usually staged according to the Ann Harbor system, being classified into four stages depending on the extent of disease ${ }^{(8)}$. Patients who are in stage I on admission have a better prognosis than those in stages II to IV, with 5 -year overall survival rates ranging from $26 \%$ to $73 \%^{(12,}$ 13). Unfortunately, oral cancer patients frequently take too long to seek care, what results in more difficult treatment and worse prognosis, as occurred in the reported case. This most likely occurs due to lack of information ${ }^{(2)}$. Therefore, a major requirement to increase lymphoma survival rates is providing more information on oral cancer to the population. Also, the addition of rituximab to combination chemotherapy in the treatment regimen has increased the proportion of cured patients ${ }^{(12)}$.

In our case report of primary DLBCL of the oral cavity we concluded that efforts should be made to diagnose this disease as rapidly as possible, since prognosis is directly related to disease staging on the patient's admission. Both health professionals and patients should be aware of the

\section{Referências}

1. COIFFIER, B. State-of-the-art therapeutics: diffuse large B-cell lymphoma. J Clin Oncol, v. 23, n. 26, p. 6387 93, 2005

2. de FARIA, P. R. et al. Clinical presentation of patients with oral squamous cell carcinoma when first seen by dentists or physicians in a teaching hospital in Brazil. Clin Oral Investig, v. 7, n. 1, p. 46-51, 2003.

3. DUARTE, E. C. B. et al. Plasmablastic lymphoma of oral mucosal type: a case report. Oral Oncol Extra, v. 41, n. 6, p. 121-4, 2005.

4. EPSTEIN, J. B. et al. Characteristics of oral and paraoral malignant lymphoma: a population-based review of 361 cases. Oral Surg Oral Med Oral Pathol Oral Radiol Endod, v. 92, n. 5, p. 519-25, 2001.

5. HIS, E. D.; YEGAPPAN, S. Lymphoma immunophenotyping: a new era in paraffin-section immunohistochemistry. Adv Anat Pathol, v. 8, n. 4, p. 218-39, 2001.

6. ISOLA, J. et al. Analysis of changes in DNA sequence copy number by comparative genomic hybridization in archival paraffin-embedded tumor samples. Am J Pathol, v. 145, n. 6, p. 1301-8, 1994.

7. JAFFE, E. S. et al. World Health Organization classification of tumors. Pathology and genetics of tumors of haematopoietic and lymphoid tissues. Lyon, France: IARC Press, 2001.

8. KOLOKOTRONIS, A. et al. Localized B-cell non-Hodgkin's lymphoma of oral cavity and maxillofacial region: a clinical study. Oral Surg Oral Med Oral Pathol Oral Radiol Endod, v. 99, n. 3, p. 303-10, 2005.

9. KRAFFT, A. E. et al. Enhanced sensitivity with a novel 
TCRgamma PCR assay for clonality studies in 569 formalin-fixed, paraffin-embedded (FFPE) cases. Mol Diagn, v. 4, n. 2, p. 119-33, 1999.

10. MESQUITA, R. A. et al. Avaliação de três métodos de extração de DNA de material parafinado para amplificação de DNA genômico pela técnica PCR. Pesq Odontol Bras, v. 15, n. 4, p. 314-9, 2001.

11. MORGENSZTERN, D. et al. Gene expression profiling in diffuse large B-cell lymphoma. Leuk Lymphoma, v. 48, n. 4, p. 669-82, 2007.

12. PAZOKI, A. et al. Primary non-Hodgkin's lymphoma of the jaws: report of 4 cases and review of the literature. J Oral Maxillofac Surg, v. 61, n. 1, p. 112-7, 2003.

13. SEHN, L. H.; CONNORS, J. M. Treatment of aggressive nonHodgkin's lymphoma: a North American perspective. Oncology (Williston Park), v. 19, n. 4, p. 26-34, 2005.

14. van der WAAL, R. I. et al. Characteristics of 40 primary extranodal non-Hodgkin lymphomas of the oral cavity in perspective of the new WHO classification and the International Prognostic Index. Int J Oral Maxillofac Surg, v. 34, n. 4, p. 391-5, 2005. 